ISSN 0258-7122 (Print), 2408-8293 (Online)

Bangladesh J. Agril. Res. 42(4): 757-766, December 2017

\title{
EFFICACY OF MANAGEMENT APPROACHES AGAINST CUCURBIT FRUIT FLY (Bactrocera cucurbitae Coquillett) OF BITTER GOURD
}

\author{
R. SARKAR ${ }^{1}$, S. DAS ${ }^{2}$, M. M. KAMAL ${ }^{2}$, K. S. ISLAM ${ }^{3}$ AND M. JAHAN ${ }^{3}$
}

\begin{abstract}
Field and laboratory studies were carried out to find out the extent of fruit fly infestation at different fruiting stages of bitter gourd as well as to determine the efficacy of some pesticidal and other control approaches applied either separately or in combination. The pesticidal efficacy of three commonly used insecticides such as secufon, malathion, karate and karanja oil as botanicals with the concentrations of $0.25 \%, 0.50 \%, 0.75 \%$ and $1.00 \%$ respectively was determined against the larvae of cucurbit fruit fly, Bactrocera cucurbitae in the laboratory based on mortality at different time intervals. All the pesticides caused maximum mortality at $72 \mathrm{~h}$ with $1.00 \%$ concentration. The level of fruit fly infestation at different fruiting stages of bitter gourd ranged from $8.91 \%$ to $88.19 \%, 9.24 \%$ to $94.89 \%$ and $5.01 \%$ to $89.27 \%$ at early, mid and late fruiting stage, respectively. Soil treatment with furadan @ $10 \mathrm{kgha}^{-1}+$ bagging of fruits showed significantly lowest infestation $(9.46 \%)$ which was ten times lower than that of untreated control $(91.43 \%)$. The other control approaches viz., sex pheromone, bait trap with secufon + cucurbit chop, bait trap consisted of secufon + banana chop reduced fruit fly infestation to a significant level. The highest number (83.67) of flies trapped at mid fruiting stage of bitter gourd was recorded in sex pheromone trap while the ratio of male and female flies ranged from 1.13 to 1.24 in the trapped individuals.
\end{abstract}

Keywords: Cucurbit fruit fly, control approaches, bitter gourd

\section{Introduction}

Climatic condition and soils of Bangladesh are highly favorable for growing various vegetables. Among them cucurbits are the major groups (Nasiruddin et al., 2004). Bitter gourd (Momordica charantia) is one of the most important cucurbitaceous vegetable in Bangladesh for its good market value which encouraged the farmers to cultivate in large scale. Although it is a summer crop but it can be grown throughout the year because of its photo insensitiveness. Cucurbits are infested by numerous insect pests which are considered to be the major obstacles for its economic production. The cucurbit fruit fly is the most destructive pests of bitter gourd causing yield loss ranging from 30-100\% (Dhillon et al., 2005; Shooker et al., 2006; Amin et al., 2011). Infestation reduces both the yield and quality of the cucurbit fruits. The female fly inserts eggs into

${ }^{1}$ Agriculture Extension Officer, Department of Agricultural Extension (DAE), Bangladesh, ${ }^{2}$ Assistant Professor, Agrotechnology Discipline, Khulna University, Bangladesh, ${ }^{3}$ Professor, Department of Entomology, Bangladesh Agricultural University (BAU), Bangladesh. 
the young fruits and the larvae, upon hatching start feeding on the internal tissues of the fruits, resulting in total loss of harvestable fruit. The larvae of the pest remain inside the infested fruits and the adults are free living. They visit fruits only at the time of oviposition and left immediately after egg deposition. So the control of the pest can hardly be assured.

Several management options, such as hydrolyzed protein spray, para-pheromone trap, spraying of ailanthus and cashew leaf extract, neem products, bagging of fruits, field sanitation, food baits, and spray of chemical insecticides (Zaman, 1995; Neupane, 2000; Akhtaruzzaman et al., 2000; Satpathy and Rai, 2002; Dhillon et al., 2005; Palaniappan and Annadurai, 2006; Jacob et al., 2007) have been used over years for the management of cucurbit fruit fly. Some of them either fail to control the pest and/or are less efficient or ineffective and even hazardous to non-target organisms and the environment (Neupane, 2000; Dhillon et al., 2005). Bagging of fruits reduced the fruit fly infestation in sweet gourd (Amin et al., 2008).

However, in Bangladesh, farmers solely rely on chemical pesticide for their welfare against this insect pests but fail in most of the cases and damage the agro-ecological balance. Unfortunately no single technique has so far been showed to be an effective and dependable to control this pest (Kapoor, 1993). Considering the fact, the present study was designed to assess the extent of fruit fly infestation at different fruiting stages of bitter gourd and evaluate the effectiveness of different control measures against cucurbit fruit fly.

\section{Materials and Methods}

\section{Experimental location, treatment and design}

The experiments were conducted both in the Entomology Field Laboratory and IPM Laboratory of the Department of Entomology, Bangladesh Agricultural University, Mymensingh. The period of the study was from 11 February to 17 May 2012 and 3 February to 12 May 2013. The experimental treatments in the field were Hand picking + Field sanitation; Soil treatment with Furadan @ $10 \mathrm{kgha}^{-1}+$ Hand picking + Field sanitation; Bait trap with Secufon 80 SP @ 1g per $100 \mathrm{~g}$ cucurbit chop; Bait trap having Secufon 80 SP @ 1g per $100 \mathrm{~g}$ banana chop; Sex pheromone with Cue-lure + Soap; Spray with Secufon 80 SP @ 0.50\% (Trichlorfon), Soil treatment with Furadan @ 10kgha ${ }^{-1}+$ Bagging; Spray with Malathion (Qiothion 57 EC) @ 0.50\% and untreated Control.

The experimental treatment in the laboratory were Spray with $0.25,0.50,0.75$ and $1.00 \%$ Secufon $80 \mathrm{SP}$ (Trichlorfon); Spray with 0.25, 0.50, 0.75 and $1.00 \%$ Malathion (Qiothion 57 EC); Spray with 0.25, 0.50, 0.75 and 1.00\% Karate 2.5 EC (Lamda cyhalothrin); Spray with $0.25,0.50,0.75$ and $1.00 \%$ Karanja oil (Botanicals) and untreated Control. The field treatments were laid out in a 
Randomized Complete Block Design (RCBD) with 3 replications. The whole experimental plot was $26.75 \mathrm{~m} \times 9.05 \mathrm{~m}$, which was divided into 3 equal blocks. Each block was divided into 9 plots where 9 treatments were allotted at random. Thus, there were $27(9 \times 3)$ unit plots with the size of $2.35 \mathrm{~m} \times 2.35 \mathrm{~m}$. Space of 1 $\mathrm{m}$ between blocks and $0.7 \mathrm{~m}$ between the plots was maintained to facilitate different intercultural operations.

\section{Raising of Crop and Application of treatments in both field and laboratory}

The experimental field was prepared by deep ploughing followed by laddering as recommended by Rashid (1993). The field layout was marked after final land preparation. Cowdung and fertilizer were applied as recommended by Rashid (1993) for bitter gourd. Four seeds were sown directly in each pit of the experimental plots. Before sowing, the seeds were treated with vitavax-200 @ $2 \mathrm{~g} / \mathrm{kg}$ seed. After sowing seeds, a light irrigation was applied. Required irrigation was applied after emergence of seedlings. Two healthy seedlings were kept in each pit to ensure healthy plant. Sevin 85WP @ 1.5kg /ha followed by a light irrigation was applied in soil around each pit in ring method and then covered with soil to avoid the infestation of cutworm. After germination of seedlings, soil of each plot was drenched with $1 \%$ solution of vitavax-200 to save the plants from the attack of anthracnose. Weeding was done and drainage facilities were provided as described by Rashid (1993).

Three plots were selected for hand picking + field sanitation. Every plot was kept clean with proper sanitation approaches. Infested fruits were picked up and number was recorded. In the same way three plots were selected for soil treatment and hand picking. Soils were treated with furadan during final land preparation and all the operations were done as per previous treatment. The bait trap consisted of $1 \mathrm{~g}$ of secufon $80 \mathrm{SP}$, mixed with $100 \mathrm{~g}$ of cucurbit chop. Ridomyl gold @ 2\% was also added to control fungus for increasing life span of bait materials. The bait was kept in a small earthen pot hung up under bamboo made hanger ( 3 randomly selected plots), $60 \mathrm{~cm}$ above ground. The old bait materials were replaced by fresh ones at an interval of 3 days. Three plots were selected for Bait trap consisting of Secufon 80 SP @ $1 \mathrm{~g}$ per $100 \mathrm{~g}$ banana chop. The bait materials were banana chop with secufon 80 SP (1 g/100 g), prepared and used like previous treatment. Sex pheromone traps consisted of 1 cue-lure tablet per plastic box with soap water and were hung up under bamboo made hanger (3 randomly selected plots), $60 \mathrm{~cm}$ above ground. The old soap water was replaced by new soap water at an interval of 7 days. Cue-lure tablet was replaced by fresh ones at an interval of 30 days. Secufon 80 SP $0.50 \%$ was sprayed on three randomly selected plots at an interval of 15 days. Soils were treated with furadan@10 kgha-1 during final land preparation. In the morning hours (8.0 $\mathrm{AM}$ to $9.30 \mathrm{AM}$ ) the entire tender fruits (3 days after anthesis) were randomly selected from 3 plots and bagged with transparent polythene bag $(30 \mathrm{~cm} \times 20 \mathrm{~cm})$ 
and brown paper $(27 \mathrm{~cm} \mathrm{x} 12 \mathrm{~cm}$ ) having few holes for aeration. Malathion 0.50 $\%$ was sprayed on three randomly selected plots at an interval of 15 days.

Collection of infested fruit (having live larvae inside the fruit) from field and 20 larvae (with fruit) were placed in each beaker (each replication). Each treatment such as secufon, malathion, karate and karanja oil at concentration of 0.25, 0.50, 0.75 and $1.00 \%$ was sprayed in each beaker replicated 5 times.

\section{Data collection and analysis}

In field, the data were recorded on number of healthy and damage fruits harvested at different stages of the fruiting e.g., early, mid and late fruiting stages. The number of healthy and damage fruits were also counted before and after treatment application. The number of fruit flies trapped in different trap at different fruiting stages of the crop was counted and recorded. The number of male and female flies trapped in different bait traps was individually counted. The number of fruit flies trapped in different trap was counted daily to determine the extent of residual effect of different traps. In laboratory, the number of larvae killed at 24, 48 and 72 hours of exposure with $0.25 \%, 0.50 \%$, $0.75 \%$ and $1.00 \%$ concentrations of secufon, malathion, karate and karanja oil, respectively were counted. Mortality percentage at $0.25 \%, 0.50 \%, 0.75 \%$ and $1.00 \%$ concentrations of secufon, malathion, karate and karanja oil, respectively were also calculated.

Number of the total fruit (TF) and infected fruit (IF) were recorded to get the infestation rate of fruit. The collected data were tabulated and analyzed using analysis of variance, with F-tests. Where the differences among treatment means were adjusted by the Duncan's Multiple Range Test (DMRT).

\section{Results and Discussion}

The results of the toxicity test of three different insecticides (secufon, malathion, karate) and one botanicals (karanja oil) against cucurbit fruit fly larvae in the laboratory were presented in Table 1 . The effect of different concentrations of insecticides on the rate of larval mortality of cucurbit fruit fly was statistically significant. Cumulative mortality of cucurbit fruit fly larvae at 24, 48 and 72 hours after treatment (HAT) indicated that each insecticide at $72 \mathrm{~h}$ showed the highest rate with $1.00 \%$ concentration. The total mortality percentage of larvae indicated that $1.00 \%$ concentration of secufon provided the highest toxic effect $(87.00 \%)$, followed by $0.75 \%$ concentration of secufon $(84 \%), 1.00 \%$ concentration of malathion $(72.00 \%), 0.50 \%$ concentration of secufon $(72.00 \%)$. Twenty five percent concentration of karanja oil showed the least toxic effect $(5.00 \%)$, followed by $0.25 \%$ of karate $(6.00 \%)$ which was higher than that untreated condition $(0.00 \%)$. 
Table 1. Cumulative mortality of the cucurbit fruit fly, Bactrocera cucurbitae larvae treated with different doses of insecticides in the laboratory condition

\begin{tabular}{|c|c|c|c|c|c|}
\hline \multirow{2}{*}{ Treatments } & \multirow{2}{*}{$\begin{array}{c}\text { Concentration } \\
(\%)\end{array}$} & \multicolumn{3}{|c|}{$\begin{array}{l}\text { Cumulative mortality at different } \\
\text { hours after treatment }\end{array}$} & \multirow{2}{*}{$\begin{array}{c}\text { Total mortality } \\
(\%)\end{array}$} \\
\hline & & $24 \mathrm{~h}$ & $48 \mathrm{~h}$ & $72 \mathrm{~h}$ & \\
\hline \multirow{5}{*}{ Secufon $80 \mathrm{SP}$} & 0.00 & 0.00 & 0.00 & 0.00 & 0.00 \\
\hline & 0.25 & 6.80 & 9.00 & 9.00 & 45.00 \\
\hline & 0.50 & 8.00 & 12.40 & 14.40 & 72.00 \\
\hline & 0.75 & 10.20 & 15.80 & 16.80 & 84.00 \\
\hline & 1.00 & 10.80 & 16.00 & 17.40 & 87.00 \\
\hline \multirow{5}{*}{$\begin{array}{c}\text { Malathion } \\
\text { (Qiothion } \\
57 \text { EC) }\end{array}$} & 0.00 & 0.00 & 0.00 & 0.00 & 0.00 \\
\hline & 0.25 & 3.60 & 5.80 & 6.80 & 34.00 \\
\hline & 0.50 & 6.20 & 9.60 & 10.80 & 54.00 \\
\hline & 0.75 & 8.00 & 12.40 & 13.80 & 69.00 \\
\hline & 1.00 & 9.20 & 12.80 & 14.40 & 72.00 \\
\hline \multirow{5}{*}{$\begin{array}{c}\text { Karate 2.5 EC } \\
\text { (Lamda } \\
\text { cyhalothrin) }\end{array}$} & 0.00 & 0.00 & 0.00 & 0.00 & 0.00 \\
\hline & 0.25 & 1.20 & 1.20 & 1.20 & 6.00 \\
\hline & 0.50 & 2.80 & 4.00 & 4.00 & 20.00 \\
\hline & 0.75 & 4.00 & 5.60 & 6.00 & 30.00 \\
\hline & 1.00 & 5.20 & 7.00 & 8.20 & 41.00 \\
\hline \multirow{5}{*}{$\begin{array}{l}\text { Karanja oil } \\
\text { (Botanicals) }\end{array}$} & 0.00 & 0.00 & 0.00 & 0.00 & 0.00 \\
\hline & 0.25 & 1.00 & 1.00 & 1.00 & 5.00 \\
\hline & 0.50 & 2.20 & 3.60 & 3.60 & 18.00 \\
\hline & 0.75 & 3.60 & 5.60 & 6.20 & 31.00 \\
\hline & 1.00 & 4.80 & 7.20 & 8.40 & 42.00 \\
\hline \multicolumn{2}{|c|}{ Level of significance } & $* *$ & $* *$ & $* *$ & $* *$ \\
\hline
\end{tabular}

Where, ${ }^{* *}=$ Significant at $1 \%$ level.

Effect of different control measures on fruit fly infestation was variable and ranged from $5.01 \%$ to $94.89 \%$ (Table 2) at early, mid and late fruiting stages of bitter gourd. The highest fruit infestation $(88.19 \%, 89.27 \%$ and $94.89 \%)$ was recorded in untreated control plots at early, mid and late fruiting stages, respectively. The lowest fruit infestation (5.01\%) was obtained in soil treatment with bagging of fruits at late fruiting stage of bitter gourd. This finding was supported by Mukherjee et al. (2007). They found that the bagging of fruits reduce the fruit infestation substantially. 
Table 2. Fruit infestation at early, mid and late fruiting stages of bitter gourd plant in the field

\begin{tabular}{l|c|c|c}
\hline \multirow{2}{*}{\multicolumn{1}{c}{ Treatments }} & \multicolumn{3}{c}{ Infestation (\%) at different fruiting } \\
& \multicolumn{3}{c}{ stages } \\
\cline { 2 - 4 } & $\begin{array}{c}\text { Early } \\
\text { stage }\end{array}$ & Mid stage & Late stage \\
\hline Hand picking + Field sanitation & $70.50 \mathrm{~b}$ & $74.83 \mathrm{~b}$ & $76.43 \mathrm{~b}$ \\
Soil treatment + Hand picking + Field sanitation & $53.38 \mathrm{c}$ & $50.52 \mathrm{c}$ & $55.39 \mathrm{c}$ \\
Bait trap (Secufon + Cucurbit chop) & $30.41 \mathrm{ef}$ & $31.74 \mathrm{e}$ & $43.49 \mathrm{~d}$ \\
Bait trap (Secufon + Banana chop) & $21.15 \mathrm{fg}$ & $27.83 \mathrm{e}$ & $23.01 \mathrm{e}$ \\
Sex pheromone (Cue-lure + Soap) & $12.49 \mathrm{~g}$ & $17.39 \mathrm{f}$ & $14.45 \mathrm{ef}$ \\
Spraying with secufon & $36.01 \mathrm{de}$ & $37.64 \mathrm{~d}$ & $36.24 \mathrm{~d}$ \\
Soil treatment + Bagging of fruits & $8.91 \mathrm{~g}$ & $9.24 \mathrm{~g}$ & $5.01 \mathrm{f}$ \\
Spraying with malathion & $47.43 \mathrm{~cd}$ & $55.06 \mathrm{c}$ & $57.30 \mathrm{c}$ \\
Control & $88.19 \mathrm{a}$ & $94.89 \mathrm{a}$ & $89.27 \mathrm{a}$ \\
Level of significance & $* *$ & $* *$ & $* *$ \\
\hline
\end{tabular}

Where, $* *=$ Significant at $1 \%$ level.

[Different letter (s) in same column indicate significance difference by DMRT]

It was observed that there was no significant difference on fruit infestation among different control measures before treatment setting (Table 3) with a range of $85.97 \%-97.15 \%$. Significant effect of different treatments on fruit infestation after treatment setting was observed (Table 3). The highest infestation $(91.43 \%)$ in fruits was recorded in untreated control plots (Table 3). Soil treatment + bagging of fruits showed significantly lower infestation $(9.46 \%)$ compared to other treatments. Other treatments including sex pheromone trap (15.02\%), secufon with banana chop (24.53\%) and secufon with cucurbit chop (32.94\%) were shown comparatively lower infestation and hand picking + field sanitation was shown second highest (74.57\%) infestation. This finding was supported by Mukherjee et al. (2007). They found that the bagging of fruits at 2 Day after Anthesis (DAA) and left for 7 days is the best treatment to reduce the fruit fly infestation. The reduced infestation in bagging was due to the fact that the bagged fruits might escape deposition of eggs by the female fruit fly. Uddin (1996) reported that fruit fly infestation was reduced in fruits of barrier + yellow pan trap + bagged of fruits. Decrease rate of fruit infestation was observed when the fruits were bagged at the initial stage (Amin, 1995; Kapoor, 1993). They explained that bagging might be successful method of prevention of oviposition. After evaluating seven treatments against the fruit fly on cucumber, Akhtaruzzaman et al. (2003) opined that the treatment Cypermethrin sprayed at 15 days intervals + bagging of fruits at 3 Day after Anthesis (DAA) and left for 5 days + bait trap might be considered as a superior method. 
The highest yield (10.88 tons $\left.\mathrm{ha}^{-1}\right)$ was obtained in plot treated with soil treatment + bagging of fruit which differ significantly from that of other treatments. Hand picking + field sanitation provided the lowest yield (3.03 tons $\left.\mathrm{ha}^{-1}\right)$ which is close to the yield of untreated plots $\left(1.08\right.$ tons $\left.\mathrm{ha}^{-1}\right)$. The highest cost-benefit ratio was found in sex pheromone trap (3.96) which differs significantly from other treatments and was followed by spraying secufon (3.12), soil treatment + hand picking + field sanitation (2.75). The lowest cost-benefit ratio was found in untreated plots (0.93). This finding was supported by Mukherjee et al. (2007). They reported that highest yield was obtained from bagging treated fruit.

Table 3. Comparative effectiveness of different control methods against fruit fly, Bactrocera cucurbitae in bitter gourd

\begin{tabular}{|c|c|c|c|c|}
\hline \multirow[b]{2}{*}{ Treatments } & \multicolumn{2}{|c|}{ Infestation (\%) } & \multirow{2}{*}{$\begin{array}{c}\text { Yield } \\
\left.\left(\text { ton }^{-1}\right)^{-1}\right)\end{array}$} & \multirow{2}{*}{$\begin{array}{l}\text { Cost: } \\
\text { benefit } \\
\text { ratio }\end{array}$} \\
\hline & $\begin{array}{c}\text { Before } \\
\text { treatment }\end{array}$ & $\begin{array}{c}\text { After } \\
\text { treatment }\end{array}$ & & \\
\hline Hand picking + Field sanitation & 97.15 & $74.57 \mathrm{~b}$ & $3.03 \mathrm{f}$ & $1.51 \mathrm{ef}$ \\
\hline $\begin{array}{l}\text { Soil treatment }+ \text { Hand picking }+ \text { Field } \\
\text { sanitation }\end{array}$ & 90.12 & $51.36 \mathrm{c}$ & $5.97 \mathrm{e}$ & $2.75 \mathrm{bc}$ \\
\hline Bait trap (Secufon + Cucurbit chop) & 96.67 & $32.94 \mathrm{~d}$ & $7.57 \mathrm{~d}$ & $1.82 \mathrm{de}$ \\
\hline Bait trap (Secufon + Banana chop) & 95.95 & $24.53 \mathrm{e}$ & $8.85 \mathrm{c}$ & $2.12 \mathrm{cde}$ \\
\hline Sex pheromone (Cue-lure + Soap) & 95.16 & $15.02 \mathrm{f}$ & $9.91 \mathrm{~b}$ & $3.96 \mathrm{a}$ \\
\hline Spraying with secufon & 98.55 & $36.72 \mathrm{~d}$ & $7.28 \mathrm{~d}$ & $3.12 \mathrm{~b}$ \\
\hline Soil treatment + Bagging of fruits & 85.97 & $9.46 \mathrm{f}$ & $10.88 \mathrm{a}$ & $1.63 \mathrm{ef}$ \\
\hline Spraying with malathion & 94.69 & $51.72 \mathrm{c}$ & $5.76 \mathrm{e}$ & $2.46 \mathrm{bcd}$ \\
\hline Control & 95.14 & $91.43 \mathrm{a}$ & $1.08 \mathrm{~g}$ & $0.93 \mathrm{f}$ \\
\hline SD & 5.76 & 2.21 & 0.37 & 0.64 \\
\hline Level of significance & NS & $* *$ & $* *$ & ** \\
\hline
\end{tabular}

Where, ${ }^{* *}=$ Significant at $1 \%$ level, NS $=$ Non significant and SD $=$ Standard deviation.

[Different letter (s) in the same column indicate significance difference by DMRT].

Comparative performance of different traps was presented in Table 4. The highest number of flies trapped at early (61.67), mid (83.67) and late fruiting stages (47.33) of plant was recorded in sex pheromone trap that differs significantly to that of other traps. The lowest number of flies trapped at early (30.33), mid (50.33) and late fruiting stages (20.00) of plant was found in bait trap consisting of secufon with cucurbit chop. The number of flies caught in bait trap having secufon (trichlorfon) + cucurbit chop, and secufon (trichlorfon) + banana chop ranged from 100.67-192.67. The result was close to the findings of Chowdhury et al. (1993). They reported that number of flies captured 115.16 to 167.48 flies trap $^{-1}$ season $^{-1}$ in poison bait traps containing trichlorfon in bitter gourd. 
Table 4. Comparison of performance among different traps at early, mid and late reproductive stages of bitter gourd

\begin{tabular}{|c|c|c|c|c|}
\hline \multirow[t]{2}{*}{ Traps } & \multicolumn{3}{|c|}{$\begin{array}{l}\text { Mean no. of flies trapped at different } \\
\text { reproductive stages of plant }\end{array}$} & \multirow{2}{*}{$\begin{array}{l}\text { Mean no. of } \\
\text { flies trapped }\end{array}$} \\
\hline & \begin{tabular}{|c|} 
Early \\
fruiting stage
\end{tabular} & $\begin{array}{l}\text { Mid fruiting } \\
\text { stage }\end{array}$ & $\begin{array}{c}\text { Late fruiting } \\
\text { stage }\end{array}$ & \\
\hline $\begin{array}{l}\text { Bait trap (secufon @ 1g / 100g } \\
\text { cucurbit chop) }\end{array}$ & $30.33 c$ & $50.33 c$ & $20.00 \mathrm{c}$ & $100.67 \mathrm{c}$ \\
\hline $\begin{array}{l}\text { Bait trap (secufon@1g } @ / 100 \mathrm{~g} \\
\text { banana chop) }\end{array}$ & $42.00 \mathrm{~b}$ & $68.00 \mathrm{~b}$ & $30.67 \mathrm{~b}$ & $140.67 b$ \\
\hline $\begin{array}{l}\text { Sex pheromone (Cue-lure @ } 1 \\
\text { trap per macha + Soap) }\end{array}$ & $61.67 \mathrm{a}$ & $83.67 \mathrm{a}$ & $47.33 \mathrm{a}$ & $192.67 \mathrm{a}$ \\
\hline SD & 2.81 & 2.49 & 2.98 & 4.43 \\
\hline Level of significance & $* *$ & $* *$ & $* *$ & $* *$ \\
\hline
\end{tabular}

Where, $* *=$ Significant at $1 \%$ level and $\mathrm{SD}=$ Standard deviation.

[Different letter (s) in the same column indicate significance difference by DMRT]

Sex ratio of fruit fly, Bactrocera cucurbitae in different bait traps at different reproductive stages of plant was presented in Table 5. Bait trap (Secufon with banana chop) trapped significantly highest number of both male $(19.00,31.67$ and 13.67) and female flies 23.00, 36.33 and 17.00) compared to bait trap having Secufon with cucurbit chop (for male 13.67, 23.67 and 9.00; for female 16.67, 26.67 and 11.00) at early, mid and late fruiting stages of plants. The ratio of male and female flies in both bait traps at different reproductive stages of plants did not showed significant difference (1.24 and 1.22). This result is in agreement with the findings of Uddin (2002) who reported that there was no significant difference in male-female ratio at reproductive stages of bitter gourd plant.

Table 5. Sex ratio of fruit fly, Bactrocera cucurbitae in two bait traps at early, mid and late reproductive stages of bitter gourd plant

\begin{tabular}{|c|c|c|c|c|c|c|c|c|c|}
\hline \multirow[b]{3}{*}{ Traps } & \multicolumn{9}{|c|}{ Mean no. of flies trapped at different reproductive stages of plant } \\
\hline & \multicolumn{3}{|c|}{ Early fruiting stage } & \multicolumn{3}{|c|}{ Mid fruiting stage } & \multicolumn{3}{|c|}{ Late fruiting stage } \\
\hline & Male & Female & $\begin{array}{c}\text { Male: } \\
\text { Female }\end{array}$ & Male & Female & \begin{tabular}{|l|} 
Male: \\
Female
\end{tabular} & Male & Female & $\begin{array}{l}\text { Male: } \\
\text { Female }\end{array}$ \\
\hline $\begin{array}{l}\text { Bait trap } \\
\text { (secufon }+ \\
\text { banana chop) }\end{array}$ & 19.00 & 23.00 & 1.21 & 31.67 & 36.33 & 1.15 & 13.67 & 17.00 & 1.24 \\
\hline $\begin{array}{l}\text { Bait trap } \\
\text { (secufon }+ \\
\text { cucurbit } \\
\text { chop) }\end{array}$ & 13.67 & 16.67 & 1.22 & 23.67 & 26.67 & 1.13 & 9.00 & 11.00 & 1.22 \\
\hline SD & 1.29 & 1.47 & 0.06 & 2.08 & 1.15 & 0.09 & 1.08 & 1.41 & 0.12 \\
\hline $\begin{array}{l}\text { Level of } \\
\text { significance }\end{array}$ & $* *$ & $* *$ & NS & $* *$ & $* *$ & NS & $* *$ & $* *$ & NS \\
\hline
\end{tabular}

Where, $* *=$ Significant at $1 \%$ level, NS $=$ Non significant and SD $=$ Standard deviation. 


\section{Conclusion}

The results of the study on the effectiveness of different management options to suppress this pest indicated that sex pheromone trap is an effective method, and the malathion spray performed better next to the bagging treatment with consideration of the cost benefit relation. Soil treatment with furadan @ $10 \mathrm{~kg}$ $\mathrm{ha}^{-1}+$ bagging of fruits provided higher yield with higher management cost which reduces the cost benefit ratio. So, growers could be motivated to apply sex pheromone trap for efficient management of cucurbit fruit fly for better yield.

\section{References}

Akhtaruzzaman, M., M.Z. Alam and M. A. Sardar. 2000. Efficiecy of different bait sprays for suppressing fruit fly on cucumber. Bull. Inst. Trop. Agric. (Kyushu University). 23:15-26.

Akhtaruzzaman, M., M.Z. Alam and M. A. Sardar. 2003. Effectiveness of some IPM packages for economic management of fruit fly on cucumber. J. Asiat. Soc. Bangladesh Sci. 29 (1): 1-10.

Amin, M. R. 1995. Effect of some indigenous materials and pesticides in controlling fruit fly, Bactrocera cucurbitae Coq. on cucumber. M.S. Thesis. Department of Entomology, Institute of postgraduate Studies in Agriculture, Gazipur, Bangladesh, $56 \mathrm{p}$.

Amin, M. R., T. Sarkar and Ik-Jo. Chun. 2011. Comparison of Host Plants Infestation Level and Life History of Fruit Fly (Bactrocera cucurbitae Coquillett) on Cucurbitaceous Crops. Hort. Environ. Biotechnol. 52(5):541-545.

Amin, M.R., R. Ara, S. Mukherjee, M.M.H. Bhuyain and M.N. Uddin. 2008. Economic evaluation of different management practices of cucurbit fruit fly (Bactrocera cucurbitae) in sweet gourd. J. Sci.Technol. (Dinajpur). 6:109-111.

Chowdhury, A. B. M. N. U., N. Islam and M. A. Karim. 1993. Efficacy of some pesticides against melon fly, Dacus cucurbitae (Coq.) on bitter gourd. (Diptera: Tephritidae). Bangladesh J. Zool. 21(2):133-139.

Dhillon, M. K., J. S. Naresh, R. Singh and N. K. Sharma. 2005. Evaluation of bitter gourd (Momordica charantia L.) genotypes for resistance to melon fruit fly, Bactrocera cucurbitae. Indian J. Pl. Prot. 33(1): 55-59.

Jacob, J., N. K. Leela, K. M. Sreekumar, R. Y. Anesh and M. Heema. 2007. Phytotoxicity of leaf extracts of multipurpose tree against insect pests in bitter gourd (Momordica charantia) and brinjal (Solanum melongena). Allelopathy J. 20 (2):1-2.

Kapoor, V. C. 1993. Indian fruit flies. Oxford \& IBH Publishing Co. Ltd. New Dellhi, India, $228 \mathrm{p}$.

Mukherjee, S., D. A. Tithi, A. A. Bachchu, R. Ara and M. R. Amin. 2007. Life history and management of cucurbit fruit fly Bactrocera cucurbitae on sweet gourd. J. Sci. technol. (Dinajpur). 5: 17-27.

Nasiruddin, M., S.N. Alam, A.K.M. Khorsheduzzaman, A.K.M.Z. Rahman, A.N.M.R. Karim, H.S. Jasmine and E.G. Rajotte. September, 2004. Integrated management of 
cucurbit fruit fly, Bactrocera cucurbitae Coquillett in Bangladesh. IPM CRSP Bangladesh Site Technical Bull. 1: 16 p.

Neupane, F. P. 2000. Integrated management of vegetable insects. CEAPRED, Bakhundol, Lalitpur, Nepal. 172 p.

Palaniappan, S. P. and K. Annadurai. 2006. Organic farming: Theory and practices. Scientific Publishers, Jodhpur, India. 257 p.

Rashid, M. M. 1993. Kumra Paribarer Sabji. In: Sabji Biggan (in Bangla). Bangla Academy, Dhaka, Bangladesh, pp. 254-256.

Satpathy, S. and S. Rai. 2002. Luring ability of indigenous food baits for fruit fly, $B$. cucurbitae (Coq.). Indian J. Ent. Res. 26(3): 249-252.

Shooker, P., F. Khayrattee and S. Permalloo. 2006. Use of maize as a trap crops for the control of melon fly, B. cucurbitae (Diptera: Tephritidae) with GF- 120. Bio-control and other control methods (Online). Availible on: httpllwww.fcla.edu/FlaEnt/fe87 p354.pdf.

Uddin, M. J. 1996. Development of suitable package(s) of IPM components for the management of selected insect pests of cucumber. M.S. Thesis Institute of Postgraduate Studies in Agriculture, Gazipur, Bangladesh. 72 p.

Uddin, M. R. 2002. Effectiveness of different control methods for the management of cucurbit fruit fly, Bactrocera cucurbitae Coq. M.S. Thesis, Bangladesh Agricultural University, Mymensingh. 46 p.

Zaman, M. 1995. Assessment of the male population of the fruit flies through kairomone baited traps and the association of the abundance levels with the environmental factors. Sarhad J. Agric. 11:657-670. 